\title{
The intensity of and recovery from photoinhibition under drought in a thermotolerant common bean compared to drought tolerant genotypes
}

\author{
D.C. MACEDO, G.R. LIMA, R.L.N. BARROS, and C. PIMENTEL* \\ Departamento de Fitotecnia, Instituto de Agronomia, Universidade Federal Rural do Rio de Janeiro, CEP \\ 23897-000, Seropédica, RJ, Brazil
}

\begin{abstract}
The chlorophyll a fluorescence parameters of four Phaseolus vulgaris L. genotypes were evaluated under drought in two greenhouse experiments. Under severe water stress, the thermotolerant genotype 'Diplomata' maintained significantly higher values of predawn leaf water potential $\left(\Psi_{\mathrm{w}}\right)$, maximum $\mathrm{F}_{\mathrm{v}} / \mathrm{F}_{\mathrm{m}}$ and effective $\left(\Phi_{\mathrm{PSII}}\right)$ quantum yield of photosystem II , and non-photochemical quenching than 'Ouro Negro', in the first experiment, and 'A 285' and 'A 222', in the second one. Among these parameters, $F_{v} / F_{m}$ showed more differences that discriminated between the genotype responses even when measured at night. Next, a difference between $F_{v} / F_{m}$ after sundown and $F_{v} / F_{m}$ at dawn on the same day (day $\Delta \mathrm{F}_{\mathrm{v}} / \mathrm{F}_{\mathrm{m}}$ ), i.e., the intensity of photoinhibition, and a difference between $\mathrm{F}_{\mathrm{v}} / \mathrm{F}_{\mathrm{m}}$ at dawn and $\mathrm{F}_{\mathrm{v}} / \mathrm{F}_{\mathrm{m}}$ after sundown on the day before (night $\Delta \mathrm{F}_{\mathrm{v}} / \mathrm{F}_{\mathrm{m}}$ ), i.e. the photoinhibition recovery, were evaluated. Day $\Delta \mathrm{F}_{\mathrm{v}} / \mathrm{F}_{\mathrm{m}}$ and night $\Delta \mathrm{F}_{\mathrm{v}} / \mathrm{F}_{\mathrm{m}}$ were significantly higher for 'Diplomata' under severe water stress in both experiments. In addition, 'Ouro Negro' in the first experiment and all the genotypes in the second showed negative values of night $\Delta \mathrm{F}_{\mathrm{v}} / \mathrm{F}_{\mathrm{m}}$ on the last day of drought when their $\Psi_{\mathrm{w}}$ were also minimal indicating no recovery from photoinhibition and the need for rehydration. At maturation, stressed plants of 'Diplomata' showed a significantly higher yield than 'Ouro Negro' in the first experiment and the same as 'A 285 ' in the second. Therefore, the thermotolerant genotype 'Diplomata' also showed drought tolerance, and the use of day $\Delta \mathrm{F}_{\mathrm{v}} / \mathrm{F}_{\mathrm{m}}$ and night $\Delta \mathrm{F}_{\mathrm{v}} / \mathrm{F}_{\mathrm{m}}$ fluorescence analysis was able to discriminate between the tolerances of these genotypes and to indicate the need for rehydration.
\end{abstract}

Additional key words: Chlorophyll $a$ fluorescence, leaf water potential, leaf soluble protein content, Phaseolus vulgaris L., water deficit.

\section{Introduction}

Common bean (Phaseolus vulgaris L.) is an important grain legume, given that it is an important source of protein, carbohydrates and minerals, especially iron, for human nutrition in Latin America and Africa, particularly for poorest people in low input agro environments (Foyer, 2019). In Brazil, common bean is an essential part of the human diet, and it is considered the "poor's meat" because of its high grain protein content (Vieira et al. 2006). However, it is a drought and temperature sensitive crop (Pimentel et al. 1999) and in this low input agriculture without irrigation, water deficit is the main environmental constraint reducing common bean yield (Blum 2011). Under drought, there is a reduction in net $\mathrm{CO}_{2}$ photoassimilation (A) and maximum quantum yield of photosystem (PS) II $\left(\mathrm{F}_{\mathrm{v}} / \mathrm{F}_{\mathrm{m}}\right)$, and stomatal control is an important common bean mechanism of drought tolerance to maintain a high leaf water potential $\left(\Psi_{\mathrm{w}}\right)($ Kramer and Boyer 1995).

In addition, nowadays, it is recognized that plants under environmental stresses, even mild stresses associated with a high photosynthetic photon flux density (PPFD) above $800 \mu \mathrm{mol} \mathrm{m}^{-2} \mathrm{~s}^{-1}$ (Long et al. 2006), can show a reduction in their net daily A specially at midday, and consequently, in PS activity, causing a metabolic oxidative stress called photoinhibition (Takahashi and Badger 2011). Therefore, reduction in A during the day can occur even at high $\Psi_{\mathrm{w}}$ (Long et al. 2006), and drought and high PPFD are usually associated in the field. However, the droughtdependent intensity of and the capacity for recovery from photoinhibition varies between genotypes (Pimentel et al. 2005, Santos et al. 2009) and can be diagnosed by chlorophyll $a$ fluorescence analysis, particularly by the $\mathrm{F}_{\mathrm{v}} / \mathrm{F}_{\mathrm{m}}$ ratio (Schreiber et al. 1994, Murchie and Lawson 2013).

Submitted 16 January 2019, last revision 8.5. 2019, accepted 24 February 2019.

Abbreviations: A - net $\mathrm{CO}_{2}$ photoassimilation; BS - before water stress; day $\Delta \mathrm{F}_{\mathrm{v}} / \mathrm{F}_{\mathrm{m}}$ - intensity of photoinhibition; $\mathrm{F}_{\mathrm{v}} / \mathrm{F}_{\mathrm{m}}-\mathrm{maximum}$ quantum yield of photosystem II; LSPC - leaf soluble protein content; night $\Delta \mathrm{F}_{\mathrm{v}} / \mathrm{F}_{\mathrm{m}}$ - recovery from photoinhibition; NPQ - nonphotochemical quenching; PPFD - photosynthetic photon flux density; PS II - photosystem II; R - after three days of rehydration; $\Psi_{\mathrm{w}}$ - predawn leaf water potential; $\Phi_{\mathrm{PSII}}$ - effective quantum yield of photosystem II.

Acknowledgements: The authors are grateful to the Coordination for the Improvement of Higher Education Personnel (CAPES) for fellowships. The authors would also like to thank a technician Marcos Paulo Santos da Fonseca for his assistance with the laboratory analysis.

* Corresponding author; e-mail: greenman@amcham.com.br 
On the other hand, Levitt et al. (1980) stated that some of the mechanisms of adaptation to drought and high temperatures could be common. Certain genes and signal transduction under both these stresses can be very similar (Neil et al. 2008), for example, the accumulation of heat shock proteins (Blum 2011). Therefore, a thermotolerant genotype could also be drought tolerant (Levitt et al. 1980, Foyer 2019).

This study aimed to evaluate the drought tolerance of a thermotolerant genotype 'Diplomata' (Pimentel et al. 2013) compared with the genotype 'Ouro Negro' with a high yield even under drought (Santos et al. 2006), and 'A 285' and 'A 222' genotypes with stomatal control under drought (Pimentel et al. 1999) using measurements of $\Psi_{\mathrm{w}}$, chlorophyll $a$ fluorescence, and leaf soluble protein content (LSPC), which can be done rapidly. In addition, our objective was to use differences in darkadapted measurements of $F_{v} / F_{m}$ performed after sundown (Pimentel et al. 2005) and just before dawn to evaluate the intensity of and capacity for recovery from photoinhibition during drought, to discriminate drought tolerance between genotypes, which can be done in a large number of naturally dark adapted plants (Pimentel et al. 2005).

\section{Material and methods}

Site and climate description: The two experiments were conducted in $10 \mathrm{~L}$ pots in a greenhouse belonging to the Crop Science Department of the Federal Rural University of Rio de Janeiro, Brazil $\left(22^{\circ} 45^{\prime} \mathrm{S}, 43^{\circ} 41^{\prime} \mathrm{W}\right.$, at an altitude of $40 \mathrm{~m}$ a.s.1.), in the same season of 2016 and 2017. The soil used for both experiments was a Kanhapudalf soil with $12.2 \%$ of water availability between field capacity and permanent wilting point, with the following composition at a depth of $0.2 \mathrm{~m}: \mathrm{pH} 5.0,18 \mathrm{mM} \mathrm{Ca}, 8 \mathrm{mM}$ $\mathrm{Mg}, 2 \mathrm{mM} \mathrm{Al}, 0.8 \mathrm{mM}$ available $\mathrm{P}$, and $2 \mathrm{mM}$ available K. During water withholding in the first experiment, air temperature, vapor pressure deficit and PPFD means were $25.5^{\circ} \mathrm{C}, 1.3 \mathrm{KPa}$, and $550 \mu \mathrm{mol} \mathrm{m} \mathrm{m}^{-2} \mathrm{~s}^{-1}$, respectively, and in the second experiment, the mean values were $27.5{ }^{\circ} \mathrm{C}$ and $1.5 \mathrm{KPa}$ with a PPFD of $850 \mu \mathrm{mol} \mathrm{m} \mathrm{m}^{-2} \mathrm{~s}^{-1}$, respectively. Under both the PPFD environments, $F_{v} / F_{m}$ values for well-watered plants were above 0.80 , which indicates A saturation as stated by Schreiber et al. (1994).

Crop management: The first study was conducted with the common bean genotypes 'Ouro Negro', a traditional genotype with a high yield even under drought (Pimentel et al. 1999, Santos et al. 2009), commonly cultivated in Brazil (Vieira et al. 2006), and 'Diplomata', a new genotype that shows temperature tolerance with a high yield under this conditions (Pimentel et al. 2013). For the second study, the drought tolerant lines 'A 285' and 'A 222' with a high stomatal control (Santos et al. 2009) were used for comparison with 'Diplomata' to confirm its drought tolerance. All the genotypes studied in both experiments had a bush growth habit with a low leaf area and the same cycle duration.

All the seeds were inoculated with Rhizobium tropici strains BR-322 and BR-520 obtained from the Brazilian Agricultural Research Corporation (Embrapa) according to the recommendations of Hungria et al. (2003). In addition, each pot was fertilized with $9 \mathrm{~g} \mathrm{~m}^{-2} \mathrm{P}$ (as simple superphosphate) and $2 \mathrm{~g} \mathrm{~m}^{-2} \mathrm{~K}$ (as potassium chloride) with a complementary fertilization with $4 \mathrm{~g} \mathrm{~m}^{-2} \mathrm{~N}$ (as urea) applied 25 days after emergence according to Vieira et al. (2006).

The pots were irrigated daily until the beginning of the drought treatment imposed 34 days after emergence in the first experiment and 38 days after emergence in the second when the plants had a leaf area of 0.270 to $0.300 \mathrm{~m}^{2}$, and all were at the pollination (pre-flowering) stage considered a drought-sensitive stage (Pimentel et al. 1999). After eight days of water deficit, the plants were rehydrated until the end of their cycle.

Water status evaluation: The predawn water tension in the xylem assumed to be equivalent to $\Psi_{\mathrm{w}}$ was measured with a Scholander pressure chamber in the central leaflet of one of the youngest fully expanded leaves of three different plants. These measurements were performed every two days during eight days of water deficit and three days of rehydration.

Chlorophyll $\boldsymbol{a}$ fluorescence parameters: Chlorophyll a fluorescence measurements were always made on the same central leaflet of another youngest fully expanded leaf using a Mini-PAM modulated fluorometer (Heinz Walz, Effeltrich, Germany) every day of water deficit and during three days of rehydration. The maximal $\left(\mathrm{F}_{\mathrm{m}}\right)$ and minimum $\left(\mathrm{F}_{\mathrm{o}}\right)$ fluorescence yields were measured in dark-adapted leaves after sundown, as proposed by Pimentel et al. (2005), and before dawn using a formula $\mathrm{F}_{\mathrm{v}} / \mathrm{F}_{\mathrm{m}}=\left(\mathrm{F}_{\mathrm{m}}-\mathrm{F}_{\mathrm{o}}\right) / \mathrm{F}_{\mathrm{m}}$ to calculate the maximum quantum yield of PS II $\left(\mathrm{F}_{\mathrm{v}} / \mathrm{F}_{\mathrm{m}}\right)$. In these dark-adapted leaves, $\mathrm{F}_{\mathrm{o}}$ was measured under a weak modulated measuring beam $\left(<0.5 \mu \mathrm{mol} \mathrm{m} \mathrm{m}^{-2} \mathrm{~s}^{-1}\right)$, and $\mathrm{F}_{\mathrm{m}}$ was attained after $0.3 \mathrm{~s}$ of a saturation pulse $\left(18000 \mu \mathrm{mol} \mathrm{m} \mathrm{m}^{-2} \mathrm{~s}^{-1}\right)$ as described by Schreiber et al. (1994). In light-adapted leaves, the effective quantum yield of PS II ( $\left.\Phi_{\mathrm{PSII}}\right)$ was measured as proposed by Maxwell and Johnson (2000) at 10 a.m. when $\mathrm{A}$ is maximal (Pimentel et al. 1999) and calculated as $\Phi_{\text {PSII }}=\left(F_{m}{ }^{\prime}-F_{t}\right) / F_{m}{ }^{\prime} ; F_{m}$ ' being the maximum fluorescence after light exposure and $F_{t}$ the transitory fluorescence. In addition, non-photochemical quenching (NPQ) was calculated with a formula $N P Q=\left(F_{m}-F_{m}{ }^{\prime}\right) / F_{m}$ ' (Murchie and Lawson 2013).

To evaluate the intensity of photoinhibition during water stress and rehydration, a difference between the values of $\mathrm{F}_{\mathrm{v}} / \mathrm{F}_{\mathrm{m}}$ measured after sundown and the $\mathrm{F}_{\mathrm{v}} / \mathrm{F}_{\mathrm{m}}$ values measured just before dawn on the same day (day $\Delta \mathrm{F}_{\mathrm{v}} / \mathrm{F}_{\mathrm{m}}$ ) was used to evaluate the intensity of photoinhibition during that day. In addition, a difference between $F_{v} / F_{m}$ measured just before dawn and $\mathrm{F}_{\mathrm{v}} / \mathrm{F}_{\mathrm{m}}$ measured after sundown the day before (night $\Delta \mathrm{F}_{\mathrm{v}} / \mathrm{F}_{\mathrm{m}}$ ) was used to evaluate the overnight recovery capacity from the photoinhibition of the day before.

Leaf soluble protein content: Before water stress and 
after three days of rehydration, the same central leaflet of the same youngest fully expanded leaf used for chlorophyll $a$ fluorescence measurements (a non-destructive process) was collected to quantify LSPC as proposed by Bradford (1976) using a spectrophotometer Spectronic 20+ (Milton Roy, USA). The LSPC was evaluated on the day before the water stress (BS) and after three days of rehydration (R). The samples were collected between 10 and 11 a.m. when photosynthetic activity is highest (Pimentel et al. 1999, Santos et al. 2009), and the leaves were wrapped in aluminum foil and stored immediately in liquid nitrogen.

Yield components: At physiological maturity 89 days after emergence in the first experiment, and 94 days after emergence in the second, 3 different plants from each treatment (the stressed and the continuously irrigated plants) and genotype were collected to evaluate yield components: the number of pods per plant, the number of grains per plant, and the grain weight per plant.

Experimental design and statistical analysis: The pots were arranged in a completely randomized design with 2 genotypes in the first experiment, and 3 genotypes in the second $\times 7$ samplings (during and after the stress) $\times 2$ treatments (water stressed and irrigated) $\times 3$ replications, 84 pots in the first experiment and 126 pots in the second in total. Data were submitted to analysis of variance, and when significant differences were detected, the means were compared and segregated using the Student-NewmanKeuls test at $5 \%$ probability. The statistical package Sisvar 5.1 Build 72 (Ferreira 2011) was used to perform the analyses.

\section{Results}

Values of $\Psi_{\mathrm{w}}$ of the genotypes decreased during water deficit for both the experiments with statistically significant differences only on the sixth and eighth days of water stress in the first experiment and on the eighth day of water stress and the second day of rehydration in the second one (Fig. 1), when 'Diplomata' showed significantly higher values of $\Psi_{w}$ compared with the other genotypes in both the experiments. After three days of rehydration, $\Psi_{w}$ values for all genotypes in both the experiments returned to values similar to those of well-watered plants on day zero, with no significant differences (Fig. 1).

For measurements of $\mathrm{F}_{\mathrm{v}} / \mathrm{F}_{\mathrm{m}}$ before dawn (Fig. 2A,C) during water deficit in the first experiment under low $\mathrm{PPFD}, \mathrm{F}_{\mathrm{v}} / \mathrm{F}_{\mathrm{m}}$ was reduced for both the genotypes only under severe stress; however, 'Diplomata' showed significantly higher values than 'Ouro Negro' on the sixth and eighth days of water stress, and the second and third days of rehydration (Fig. 2A). In the second experiment, when PPFD was higher than in the first experiment, differences in $F_{v} / F_{m}$ before dawn began on the third day of water stress, when 'Diplomata' and 'A 285' showed higher $F_{v} / F_{m}$ values than 'A 222' (Fig. 2C). Significant differences were also observed on the fourth day, when 'Diplomata' $F_{v} / F_{m}$ was higher than that of 'A 285 ' and 'A 222', on the sixth

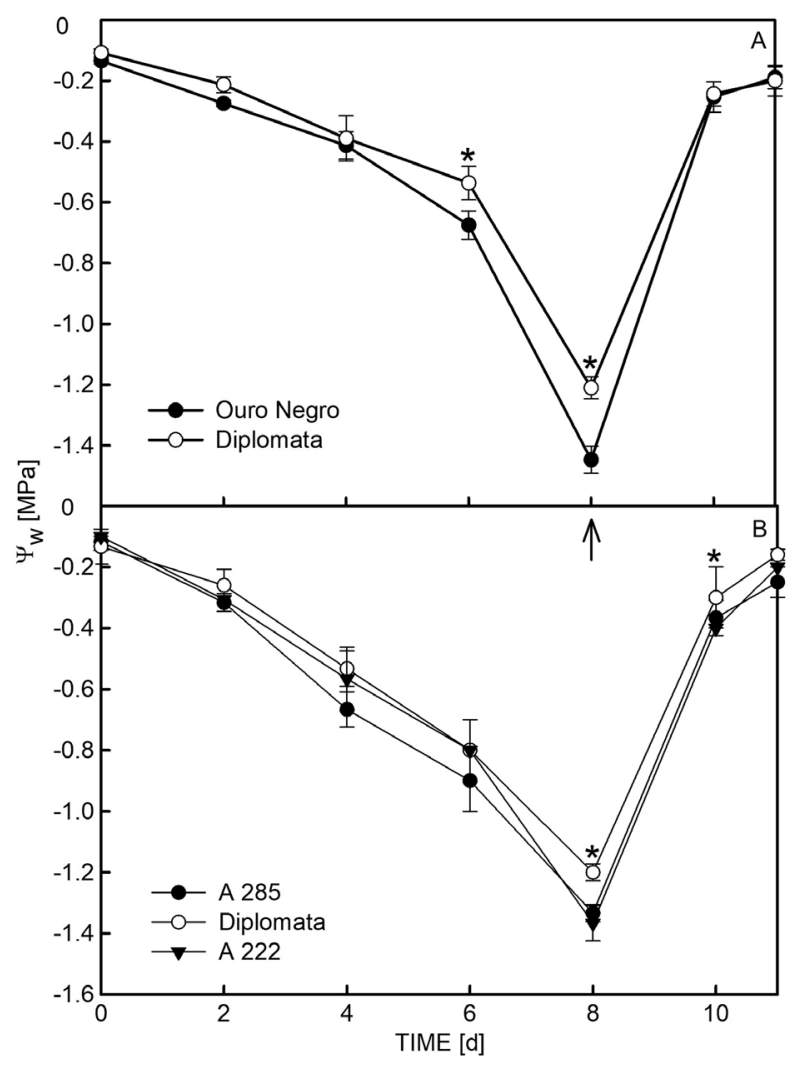

Fig. 1. Daily values of predawn leaf water potential $\left(\Psi_{w}\right)$ of two genotypes 'Ouro Negro' and 'Diplomata' in the first experiment $(A)$, and three genotypes 'A 285', 'Diplomata', and 'A 222' in the second experiment $(B)$ during eight days of water stress and three days of rehydration in both experiments. The arrows indicate the day of rehydration, and the asterisks indicate significant differences. Means include three replicates per treatment $(\mathrm{P}<0.05)$.

day when 'Diplomata' showed higher $\mathrm{F}_{\mathrm{v}} / \mathrm{F}_{\mathrm{m}}$ values than 'A 222', but 'A 285' did not significantly differ from the others, on the seventh day when 'Diplomata' and 'A 285' presented higher $F_{v} / F_{m}$ values than 'A 222', and on the eighth and last days of stress, when 'Diplomata' showed higher $F_{v} / F_{m}$ values than the other two genotypes, and 'A 285' had higher values than 'A 222' (Fig. 2C). During rehydration on the first, second and third days, 'Diplomata' presented significantly higher $\mathrm{F}_{\mathrm{v}} / \mathrm{F}_{\mathrm{m}}$ values than the other genotypes, and 'A 285 ' had higher $\mathrm{F}_{\mathrm{v}} / \mathrm{F}_{\mathrm{m}}$ values than 'A 222' (Fig. 2C).

For measurements of $\mathrm{F}_{\mathrm{v}} / \mathrm{F}_{\mathrm{m}}$ after sundown (Fig. 2B,D) during water stress in the first experiment under low PPFD, 'Diplomata' showed significantly higher values of $F_{v} / F_{m}$ than 'Ouro Negro' on the sixth, seventh and eighth days of water stress and from the first to the third day of rehydration (Fig. 2B). In the second experiment under higher PPFD, the $\mathrm{F}_{\mathrm{v}} / \mathrm{F}_{\mathrm{m}}$ values showed greater reductions than in the first experiment (Fig. 2), but less significant differences were observed. These differences occurred only on the seventh day of stress when 'Diplomata' and 'A 285' showed higher values of $F_{v} / F_{m}$ at night than 'A 222', and the eighth and last days of water deficit when 'Diplomata' showed higher values than 'A 285' and 


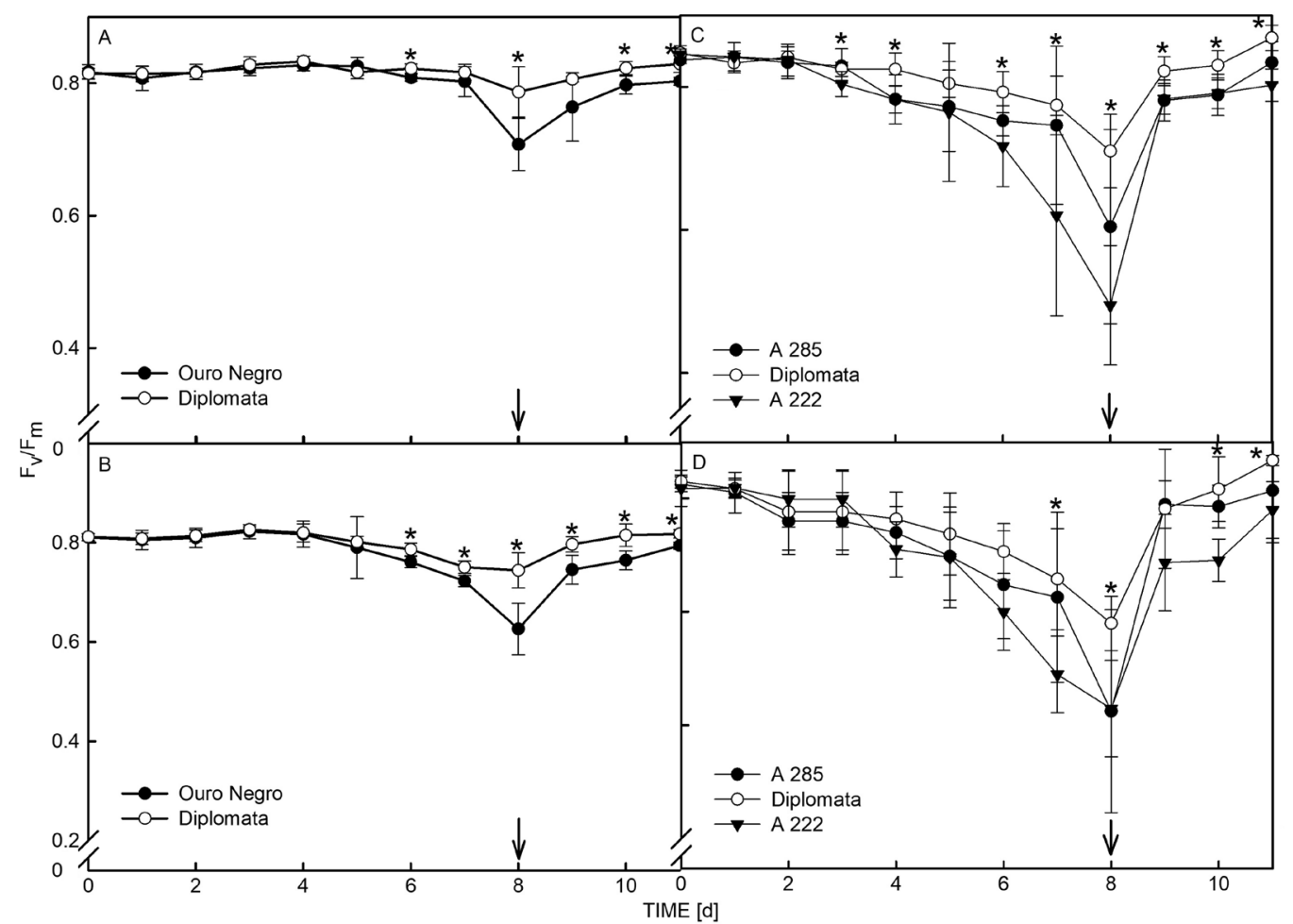

Fig. 2. Maximum quantum yield of photosystem II $\left(\mathrm{F}_{\mathrm{v}} / \mathrm{F}_{\mathrm{m}}\right)$ before dawn $(A, C)$ and after sunset $(B, D)$ of two genotypes 'Ouro Negro' and 'Diplomata' in the first experiment, and three genotypes, 'A 285', 'Diplomata', and 'A 222', in the second experiment during eight days of water stress and three days of rehydration in both experiments. The arrows indicate the day of rehydration and the asterisks indicate significant differences. Means include three replicates per treatment $(\mathrm{P}<0.05)$.

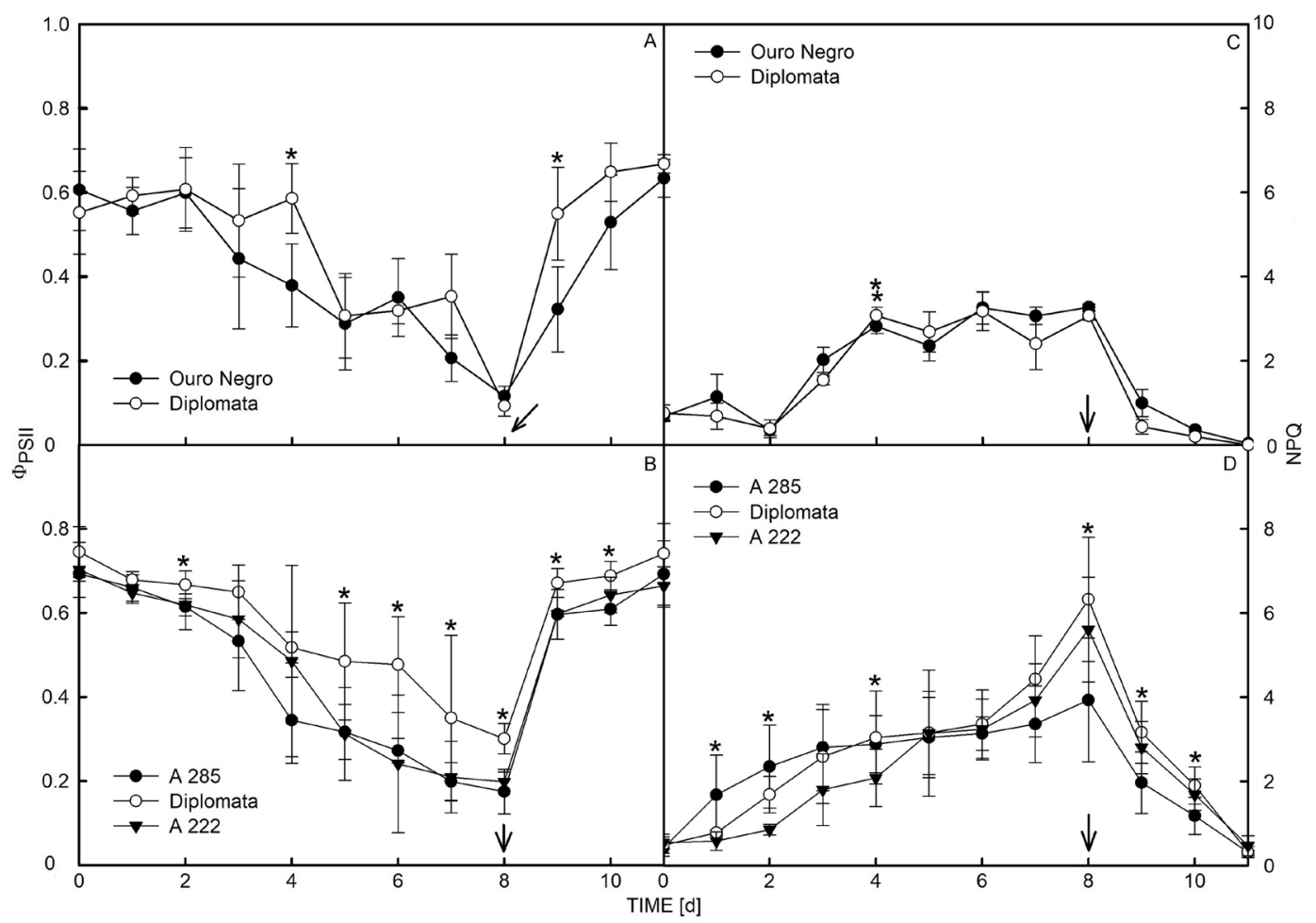

Fig. 3. Effective quantum yield of photosystem II $\left(\Phi_{\mathrm{PSII}}\right)(A, B)$ and non-photochemical quenching (NPQ) $(C, D)$ of two genotypes 'Ouro Negro' and 'Diplomata' in the first experiment, and three genotypes, 'A 285', 'Diplomata', and 'A 222' in the second experiment during eight days of water stress and three days of rehydration in both experiments. The arrows indicate the day of rehydration and the asterisks indicate significant differences. Means include three replicates per treatment $(\mathrm{P}<0.05)$. 


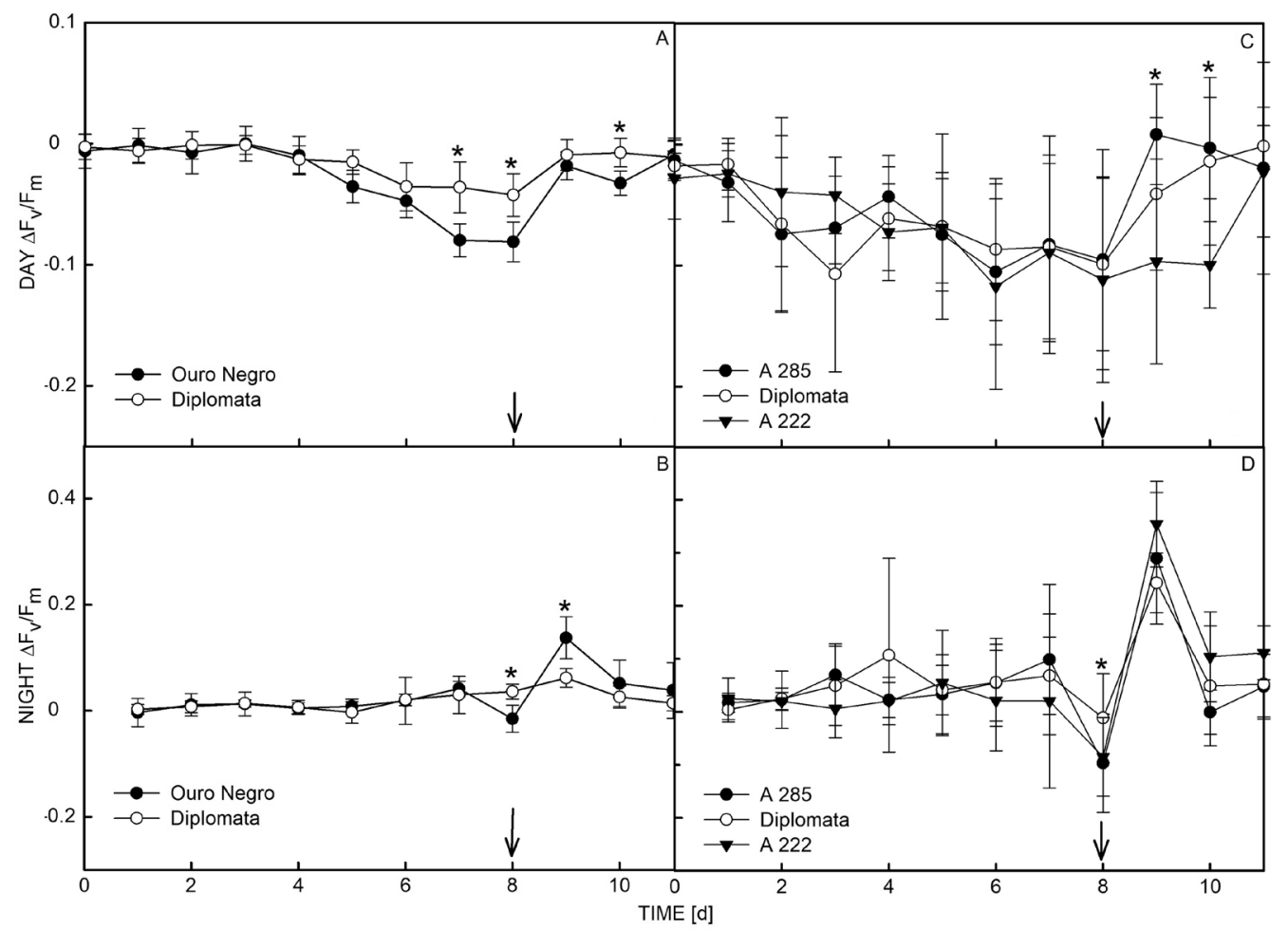

Fig. 4. Intensity of photoinhibition (day $\Delta \mathrm{F}_{\mathrm{v}} / \mathrm{F}_{\mathrm{m}}$ ), i.e., the value of maximum quantum yield of photosystem II $\left(\mathrm{F}_{\mathrm{v}} / \mathrm{F}_{\mathrm{m}}\right)$ after sundown minus the value of $\mathrm{F}_{\mathrm{v}} / \mathrm{F}_{\mathrm{m}}$ at dawn on the same day of two genotypes 'Ouro Negro' and 'Diplomata' in the first experiment $(A)$, and three genotypes 'A 285', 'Diplomata', and 'A 222', in the second experiment $(C)$. Photoinhibition recovery (night $\Delta \mathrm{F}_{\mathrm{v}} / \mathrm{F}_{\mathrm{m}}$ ), i.e. the value of maximum quantum efficiency of photosystem II $\left(\mathrm{F}_{\mathrm{v}} / \mathrm{F}_{\mathrm{m}}\right)$ at dawn minus the value of $\mathrm{F}_{\mathrm{v}} / \mathrm{F}_{\mathrm{m}}$ after sundown on the day before in the first experiment $(B)$ and in the second experiment $(D)$, during eight days of water stress and three days of rehydration in both experiments. The arrows indicate the day of rehydration and the asterisks indicate significant differences. Means include three replicates per treatment $(\mathrm{P}<0.05)$.

'A 222', which shows no significant differences between each other (Fig. 2D). During rehydration, 'Diplomata' and 'A 285 ' showed higher values of $F_{v} / F_{m}$ after sundown than 'A 222' on the second day, and on the third day of rehydration, 'Diplomata' presented higher values of $F_{v} / F_{m}$ than 'A 222' after sundown, while 'A 285' was similar to both the genotypes (Fig. 2D).

On light-adapted leaves of plants in the first experiment after four days of water deficit, $\Phi_{\text {PSII }}$ of 'Diplomata' was around 0.6 , significantly higher than for 'Ouro Negro', and over the next four days of water stress, $\Phi_{\text {PSII }}$ continued to fall for both the genotypes with no significant differences until reaching a value of around 0.1 on the eighth and last days of water stress. After rehydration, the values increased (Fig. $3 A$ ), and on the first day of rehydration, 'Diplomata' showed a significantly higher value for $\Phi_{\text {PSII }}$ compared with 'Ouro Negro', and after three days of rehydration, the values for $\Phi_{\text {PSII }}$ of both the genotypes were close to those of well-watered plants on day zero in this first experiment (Fig. 3A). However, in the second experiment under higher PPFD, 'Diplomata' had a significantly higher $\Phi_{\text {PSII }}$ than the other two genotypes, 'A 285' and 'A 222', from the second day (Fig. $3 B$ ), as well as on the fifth, sixth, seventh, eighth, and last days of drought. After rehydration, 'Diplomata' $\Phi_{\text {PSII }}$ was also significantly higher than that for the other two genotypes on the first day, whereas on the second day of rehydration, it was significantly higher than in 'A 285', and 'A 222' was similar to the other two, and on the third day of rehydration, the values returned to values similar to those of well-watered plants on day zero of this second experiment (Fig. 3B).

On the other hand, in both the experiments, NPQ values (Fig. 3C,D) increased following the imposition of water stress and decreased with rehydration. In the first experiment, NPQ values were significantly different between the genotypes only on the fourth day of stress (Fig. 3C), when $\Phi_{\text {PSII }}$ was also different (Fig. $3 A$ ), with 'Ouro Negro' showing a significantly higher value of NPQ (Fig. $3 C$ ) and a lower $\Phi_{\text {PSII }}$ than 'Diplomata' (Fig. $3 A$ ). In the second experiment, there were more significant differences for NPQ among the genotypes even under mild stress, beginning on the first and second days of water stress imposition (Fig. 3D) when 'A 285' showed significantly higher NPQ values than 'A 222' but the same as 'Diplomata' on both days. On the fourth day of drought, 'A 285' and 'Diplomata' showed higher NPQ values than 'A 222', and on the eighth and last days of stress, 'Diplomata' and 'A 222' showed higher NPQ values than 'A 285' (Fig. 3D). During water deficit, the genotype 'A $285^{\prime}$ ' presented a rapid increase in NPQ at the beginning of the stress and maintained this value until the last day of drought (Fig. 3D). 
Table 1. Leaf soluble protein content of 'Ouro Negro' and 'Diplomata' in the first experiment, and 'A 285', 'Diplomata', and 'A 222' in the second experiment, submitted to eight days of water deficit and three days of rehydration in both experiments, $n=3$; means followed by the same letter within a column are not significantly different $(\mathrm{P}<0.05)$. BS - sampling before stress; $\mathrm{R}$ - sampling on the third day of rehydration.

\begin{tabular}{llc}
\hline First experiment (2016) & \multicolumn{2}{l}{ Protein content $\left[\mathrm{mg}^{-1} \mathrm{~g}^{-1}(\mathrm{f} . \mathrm{m}).\right]$} \\
Genotype & $\mathrm{BS}$ & $\mathrm{R}$ \\
\hline 'Ouro Negro' & $2.95 \mathrm{~b}$ & $2.99 \mathrm{~b}$ \\
'Diplomata' & $3.64 \mathrm{a}$ & $4.26 \mathrm{a}$ \\
\hline
\end{tabular}

\begin{tabular}{llc}
\hline $\begin{array}{l}\text { Second experiment (2017) } \\
\text { Genotype }\end{array}$ & \multicolumn{2}{l}{ Protein content $\left[\mathrm{mg} \cdot \mathrm{g}^{-1}\right.$ (f.m.) $]$} \\
\hline 'A 285' & $4.18 \mathrm{a}$ & $\mathrm{R}$ \\
'Diplomata' & $3.90 \mathrm{~b}$ & $4.81 \mathrm{a}$ \\
'A 222' & $3.28 \mathrm{c}$ & $5.04 \mathrm{a}$ \\
\hline
\end{tabular}

In order to evaluate the intensity of the effects of photoinhibition on the genotypes using a more stable chlorophyll $a$ fluorescence parameter $\mathrm{F}_{\mathrm{v}} / \mathrm{F}_{\mathrm{m}}$ measured at night (Fig. 2), day $\Delta \mathrm{F}_{\mathrm{v}} / \mathrm{F}_{\mathrm{m}}$, i.e., the photoinhibitory reduction in $\mathrm{F}_{\mathrm{v}} / \mathrm{F}_{\mathrm{m}}$ during the day, are presented in Fig. $4 \mathrm{~A}$ and $C$ for each experiment. In the first experiment, 'Diplomata' showed a significantly smaller effect, i.e., higher values for day $\Delta \mathrm{F}_{\mathrm{v}} / \mathrm{F}_{\mathrm{m}}$ than 'Ouro Negro' on the seventh and eighth days of water stress and the second day of rehydration (Fig. 4A). In the second experiment, with the increased PPFD, the day $\Delta \mathrm{F}_{\mathrm{v}} / \mathrm{F}_{\mathrm{m}}$ values were below 0.0 from the first to the last day of stress (Fig. 4C) indicating a higher intensity of photoinhibition than in the first experiment; however, no significant differences were observed during water deficit, only on the first and second days of rehydration, when 'A 285 ' showed higher values of day $\Delta \mathrm{F}_{\mathrm{v}} / \mathrm{F}_{\mathrm{m}}$ than 'Diplomata' and 'A 222'. For both the experiments on the last day of rehydration, day $\Delta \mathrm{F}_{\mathrm{v}} / \mathrm{F}_{\mathrm{m}}$ values were the same for all the genotypes (Fig. $4 A, C$ ).

On the other hand, night $\Delta \mathrm{F}_{\mathrm{v}} / \mathrm{F}_{\mathrm{m}}$ were used to analyze the overnight recovery capacity from photoinhibition effects that occurred the day before (Fig. $4 B, D$ ). In the first experiment, significant differences were verified with higher and positive values of night $\Delta \mathrm{F}_{\mathrm{v}} / \mathrm{F}_{\mathrm{m}}$ for 'Diplomata' on the eighth and last days of drought when 'Ouro Negro' showed a negative night $\Delta \mathrm{F}_{\mathrm{v}} / \mathrm{F}_{\mathrm{m}}$ value (Fig. $4 B$ ). In the second experiment, 'Diplomata' also showed significantly higher but slightly negative night $\Delta \mathrm{F}_{\mathrm{v}} / \mathrm{F}_{\mathrm{m}}$ values than the other two genotypes (Fig. $4 D$ ) on the eighth and last days of water stress. On the eighth day of drought in both the experiments, all the genotypes showed negative values of night $\Delta \mathrm{F}_{\mathrm{v}} / \mathrm{F}_{\mathrm{m}}$ (Fig. $5 B, D$ ) when $\Psi_{\mathrm{w}}$ values also nearly reached $-1.5 \mathrm{MPa}$ (Fig. 1) indicating a threshold negative value of night $\Delta \mathrm{F}_{\mathrm{v}} / \mathrm{F}_{\mathrm{m}}$ for water-stressed plant recovery through rehydration on the eighth day of drought. After rehydration in the first experiment, 'Ouro Negro' showed a significantly higher night $\Delta \mathrm{F}_{\mathrm{v}} / \mathrm{F}_{\mathrm{m}}$ than 'Diplomata' (Fig. 4B), whereas in the second experiment, no differences were observed during rehydration (Fig. $4 D$ ).

The LSPC was evaluated BS and after three days of R with significant differences among genotypes in both the experiments (Table 1). In the first experiment, 'Diplomata' showed a significantly higher LSPC than 'Ouro Negro' $\mathrm{BS}$ and after R, whereas in the second experiment BS,

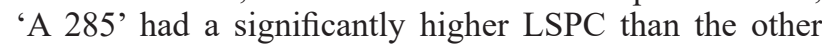
two genotypes, and 'A 222' showed a significantly lower LSPC than the others, but in R, all three genotypes showed a similar LSPC with values very close to or even higher than BS (Table 1).

In the first experiment, water deficit did not affect the individual grain weight (data not shown), number of pods per plant and grain weight per plant for 'Ouro Negro' causing a reduction only in the number of grains per plant, whereas for 'Diplomata' (Table 2), drought significantly reduced all yield components compared with control plants. However, comparisons among the yield components of the water-stressed genotypes, in the first experiment (Table 2), show a significant difference only for grain weight per plant between the stressed plants with higher yield values for 'Diplomata' than for 'Ouro Negro'. In the second experiment, the water deficit did not affect grain weight (data not shown), but reduced all the other yield components of all three genotypes, though they all had very similar grain weight per plant under drought (Table 2). However, a higher number of pods per plant was verified for 'Diplomata' compared with 'A 285 ' and

Table 2. The numbers of pods per plant, grains per plant, and grain weight per plant of 'Ouro Negro' and 'Diplomata' in the first experiment, and 'A 285', 'Diplomata', and 'A 222' in the second experiment, submitted to eight days of drought or continuously irrigated in both experiments, $n=3$. Uppercase letters represent statistical analysis between treatments (control and stress), and lowercase letters represents significant differences between genotypes for the same treatment $(\mathrm{P}<0.05)$.

\begin{tabular}{llllrrr}
\hline \multirow{2}{*}{ Variable } & & \multicolumn{2}{c}{ First Experiment (2016) } & \multicolumn{2}{c}{ Second Experiment (2017) } \\
& Treatment & 'Ouro Negro' & 'Diplomata' & 'A 285' & 'Diplomata' & 'A 222' \\
\hline Number of pods per plant & control & $12.00 \mathrm{Aa}$ & $13.00 \mathrm{Aa}$ & $10.00 \mathrm{Ab}$ & $14.00 \mathrm{Aa}$ & $8.50 \mathrm{Ab}$ \\
& stress & $10.00 \mathrm{Aa}$ & $10.00 \mathrm{Ba}$ & $5.00 \mathrm{Bb}$ & $8.00 \mathrm{Ba}$ & $4.00 \mathrm{Bb}$ \\
Number of grains per plant & control & $51.00 \mathrm{Aa}$ & $67.00 \mathrm{Aa}$ & $41.50 \mathrm{Aa}$ & $42.25 \mathrm{Aa}$ & $31.25 \mathrm{Ab}$ \\
& stress & $32.00 \mathrm{Ba}$ & $43.00 \mathrm{Ba}$ & $27.75 \mathrm{Ba}$ & $28.75 \mathrm{Ba}$ & $16.00 \mathrm{Bb}$ \\
Grain weight per plant $[\mathrm{g}]$ & control & $8.49 \mathrm{Aa}$ & $14.85 \mathrm{Aa}$ & $8.51 \mathrm{Aa}$ & $10.23 \mathrm{Aa}$ & $6.03 \mathrm{Ab}$ \\
& stress & $7.07 \mathrm{Ab}$ & $10.11 \mathrm{Ba}$ & $5.73 \mathrm{Ba}$ & $6.03 \mathrm{Ba}$ & $3.98 \mathrm{Bb}$ \\
\hline
\end{tabular}


'A 222' under water deficit, and a significantly higher number of grains per plant and grain weight per plant was verified for stressed plants of 'Diplomata' and 'A 285' than for 'A 222', which was more drought sensitive.

\section{Discussion}

In this study, after eight days of water stress, $\Psi_{\mathrm{w}}$ was close to $-1.5 \mathrm{MPa}$ for 'Ouro Negro' in the first experiment (Fig. 1A) and 'A 285' and 'A 222' in the second experiment (Fig. $1 B$ ). This $\Psi_{\mathrm{w}}$ is considered as a threshold value under a severe water deficit for common bean (Kramer and Boyer 1995, Pimentel et al. 1999) and thus, the plants were rehydrated and evaluated for three days and then at maturation.

According to the results in the first experiment (Fig. 1), 'Diplomata' maintained a significantly higher $\Psi_{\mathrm{w}}$ than 'Ouro Negro' only under the severe stress on the sixth and eighth days of water deficit, but not during rehydration (Fig 1A), and in the second experiment, only on the eighth and last days of stress and on the first day of rehydration, with 'Diplomata' showing a significantly higher $\Psi_{\mathrm{w}}$ than 'A 285' and 'A 222' (Fig. 1B). Therefore, 'Diplomata' have probably a higher water use efficiency due to a rapid stomatal closure as shown by Santos et al. (2009), or to a slower but durable response by genetic control, which reduces stomata opening in response to light (Głowacka et al., 2018) when compared to 'A 285' and 'A 222'. Stomatal control is considered as one of the principal mechanisms for drought tolerance in common bean as well as the deep of roots and a lower leaf area (Pimentel et al. 1999). However, the genotypes evaluated were selected to have a bush growth habit and, therefore, they have almost the same leaf area which is reduced by drought (Vieira et al.2006). In addition, in pot experiments, root extension is lower than in the field (Kramer and Boyer 1995). Thus, in pot experiments with common bean under drought, the principal drought tolerance mechanism is stomatal control, and Santos et al. (2009) showed a rapid stomatal closure in 'A 285 ' and 'A 222'. After three days of rehydration, the $\Psi_{\mathrm{w}}$ values of all the plants submitted to drought were similar to the values observed for well-watered plants (Fig.1) in agreement with Santos et al. (2006).

Drought inhibits A in part due to an imbalance between light capture and its usage (Takahashi and Badger 2011). Chlorophyll a fluorescence parameters are quickly measured and can be used to discriminate the photosynthetic performance of a large number of plants under abiotic and biotic stresses (Schreiber et al. 1994, Baker 2008). Among these, the parameter $\mathrm{F}_{\mathrm{v}} / \mathrm{F}_{\mathrm{m}}$, obtained in dark-adapted leaves, is a very useful parameter to discriminate different responses to stresses by each genotype (Pimentel et al. 2005, Murchie and Lawson 2013), moreover, it varies less than the parameters obtained on light-adapted leaves, which depend on an incident PPFD (Mishra et al. 2012). To measure $\mathrm{F}_{\mathrm{v}} / \mathrm{F}_{\mathrm{m}}$ in a large number of dark-adapted plants, it is easier and quicker to do these measurements at night rather than using dark leaf clips (Pimentel et al. 2005).

In the first experiment under the lower PPFD (a mean of $\left.550 \mu \mathrm{mol} \mathrm{m} \mathrm{m}^{-2} \mathrm{~s}^{-1}\right)$, the $\mathrm{F}_{\mathrm{v}} / \mathrm{F}_{\mathrm{m}}$ values at dawn and after sundown were reduced, with an increase in $\mathrm{F}_{\mathrm{o}}$ (data not shown), for both the genotypes only under the severe water deficit (Fig. 2A,C); however, they were reduced from the third day in the second experiment with three genotypes (Fig. 2C) under the higher PPFD (a mean of $\left.850 \mu \mathrm{mol} \mathrm{m} \mathrm{m}^{-2} \mathrm{~s}^{-1}\right)$. The high PPFD anticipated reduction in $F_{v} / F_{m}$ under the drought. Nevertheless, the $F_{v} / F_{m}$ values obtained after sundown in both the experiments showed a greater reduction than at dawn when the plants recovered from a day photoinhibitory effect during night (Fig. 2). In the first and second experiments after sundown or at dawn, 'Diplomata' showed significantly higher values of $F_{v} / F_{m}$ then all the other genotypes (Fig. 2A,C).

According to Schreiber et al. (1994), $\Phi_{\mathrm{PSII}}$ is related to the proportion of energy absorbed by the chlorophyll molecules associated with PS II activity, which is actually used in photochemistry. A reduction in its value is associated with the closure of reaction centers and in an increase in power dissipation processes in the form of heat indicated by an increase in NPQ (Baker 2008, Murchie and Lawson 2013). In both the experiments, the values of $\Phi_{\text {PSII }}$ (Fig. 3A,B) diminished with the imposition of water stress and recovered to the baseline values (day zero) after three days of rehydration, whereas NPQ varied inversely (Fig. 3C,D).

Under the water deficit, $\Phi_{\text {PSII }}$ showed an earlier and more intense decrease than $F_{v} / F_{m}$ (Fig. 2) but with a greater variability probably due to variations in incident PPFD. In the first experiment under the low PPFD of $550 \mu \mathrm{mol}$ $\mathrm{m}^{-2} \mathrm{~s}^{-1}$, the $\Phi_{\text {PSII }}$ values for 'Diplomata' were significantly higher than for 'Ouro Negro' only on the fourth day of stress and the first day of rehydration (Fig. $3 A$ ). However, in the second experiment under the higher PPFD, $\Phi_{\mathrm{PSII}}$ was significantly higher for 'Diplomata' on the second, fifth, sixth and eighth days of water deficit and the first and second days of rehydration (Fig. 3B). Therefore, an experiment to evaluate chlorophyll $a$ fluorescence under drought with a PPFD above $800 \mu \mathrm{mol} \mathrm{m} \mathrm{m}^{-2} \mathrm{~s}^{-1}$ could more clearly discriminate between the responses of different genotypes than under a lower PPFD as can be seen in these experiments. These findings could result in a reduced potential yield of water-stressed plants (Long et al. 2006) especially in the second experiment under the higher photoinhibitory effect (Table 2).

In contrast, the values for NPQ increased with water stress imposition and decreased with rehydration for both the experiments in agreement with results obtained by Santos et al. (2009), but at the end of the stress, NPQ values were almost double in the second experiment compared with the first one (Fig. 3C,D) probably due to the higher incident PPFD, which caused an early diminution of $\Phi_{\text {PSII }}$ (Fig. 3A,B) and an increase in NPQ in the second experiment (Fig. $3 C, D$ ). In the first experiment under the low PPFD, there was just one significant difference for NPQ, a higher value for 'Ouro Negro' on the fourth day of the deficit (Fig. 3C). However, in the second experiment (Fig. 3D) under the higher PPFD, NPQ was significantly higher for 'A 285 ' than for the other genotypes on the first and second days of stress, and on the eighth and last 
days of stress, 'Diplomata' and 'A 222' showed higher NPQ values than 'A 285'. On the first and second days of rehydration, 'Diplomata' showed significantly higher NPQ values than the others (Fig. 3D).

Thus, in the second experiment under the higher PPFD, there were more significant differences in $\Phi_{\text {PSII }}$ (Fig. 3A,B) and NPQ (Fig. 3C,D), and 'Diplomata' showed higher values of $\Phi_{\text {PSII }}$ and NPQ on the last day of drought only in the second experiment, which means an increased activity of mechanisms for dissipating energy and repair, NPQ, maintaining a higher PS II activity, and $\Phi_{\mathrm{PSII}}$ under the high PPFD. Therefore, controlling PFFD, whenever possible above $800 \mu \mathrm{mol} \mathrm{m} \mathrm{m}^{-2} \mathrm{~s}^{-1}$ (Long et al. 2006), is essential for evaluating photoinhibitory effects associated with drought in order to discriminate distinct genotype responses of PS activity, since in the field, drought is generally associated with a high PPFD due to a clear sky (Takahashi and Badger 2011).

The photooxidative process known as photoinhibition can be assessed by a reduction in $F_{v} / F_{m}$ (Fig. 2), which is used as a stress indicator (Baker 2008, Pimentel et al. 2005). In addition, day $\Delta \mathrm{F}_{\mathrm{v}} / \mathrm{F}_{\mathrm{m}}$ can be used for indication of the intensity of photoinhibition during this day (Fig. 4A,C) in a such a way that it reduces $\mathrm{F}_{\mathrm{v}} / \mathrm{F}_{\mathrm{m}}$ of plants making day $\Delta \mathrm{F}_{\mathrm{v}} / \mathrm{F}_{\mathrm{m}}$ more or less negative. Using this analysis, in the first experiment before and during the first three days of drought, day $\Delta \mathrm{F}_{\mathrm{v}} / \mathrm{F}_{\mathrm{m}}$ of the plants was close to zero (Fig. 4A) indicating no evident photoinhibitory effect during the initial days of stress, but from the fourth day of stress onward, day $\Delta \mathrm{F}_{\mathrm{v}} / \mathrm{F}_{\mathrm{m}}$ became more negative. In addition, 'Diplomata' showed higher day $\Delta \mathrm{F}_{\mathrm{v}} / \mathrm{F}_{\mathrm{m}}$ values than 'Ouro Negro' on the seventh and eighth days of drought and on the second day of rehydration (Fig. 4A) indicating a lower photoinhibitory effect on 'Diplomata'. However, in the second experiment under the higher PPFD, the day $\Delta \mathrm{F}_{\mathrm{v}} / \mathrm{F}_{\mathrm{m}}$ values were below zero from the first to the last day of stress (Fig. 4C) indicating a higher intensity of photoinhibition than in the first experiment, but there were no significant differences during the water deficit. 'A 285' showed higher values of day $\Delta \mathrm{F}_{\mathrm{v}} / \mathrm{F}_{\mathrm{m}}$ than 'Diplomata' and 'A 222' only on the first and second days of rehydration, whereas on the last day of rehydration, the day $\Delta \mathrm{F}_{\mathrm{v}} / \mathrm{F}_{\mathrm{m}}$ values were the same for all genotypes but showing a fast recovery for the most drought sensitive genotype 'A 222' (Fig. 4C). Thus, even though the values of $F_{v} / F_{m}$ before dawn or after sundown (Fig. 2) showed more significant differences between genotypes than the day $\Delta \mathrm{F}_{\mathrm{v}} / \mathrm{F}_{\mathrm{m}}$ analysis (Fig. $4 A, C$ ), the degree of reduction in day $\Delta \mathrm{F}_{\mathrm{v}} / \mathrm{F}_{\mathrm{m}}$ can indicate the intensity of photoinhibition as shown in these two experiments under different PPFDs (Fig. 4A,C).

To evaluate the capacity for recovery overnight from photoinhibitory effects of the day before, night $\Delta \mathrm{F}_{\mathrm{v}} / \mathrm{F}_{\mathrm{m}}$ was used to analyze this capacity associated with water deficit effects. According to the results obtained (Fig. 4B,D), significant differences for the values of night $\Delta \mathrm{F}_{\mathrm{v}} / \mathrm{F}_{\mathrm{m}}$ during drought were detected only on the eighth and last day of stress when 'Diplomata' showed higher night $\Delta \mathrm{F}_{\mathrm{v}} / \mathrm{F}_{\mathrm{m}}$ values compared with the other genotypes in both the experiments (Fig. 4B,D), whereas 'Ouro Negro' showed a higher night $\Delta \mathrm{F}_{\mathrm{v}} / \mathrm{F}_{\mathrm{m}}$ value on the first day of rehydration (Fig. 4B) and 'A 222' showed a faster recovery of night $\Delta \mathrm{F}_{\mathrm{v}} / \mathrm{F}_{\mathrm{m}}$ values during rehydration (Fig. $4 D$ ), which is considered a desirable trait for breeding programs on drought tolerance for common bean (Santos et al. 2006). Moreover, on the last day of water deficit, for the first time, 'Ouro Negro' showed a negative value for night $\Delta \mathrm{F}_{\mathrm{v}}$ / $F_{m}$ in the first experiment under the lower PPFD, and all three genotypes also showed a negative night $\Delta \mathrm{F}_{\mathrm{v}} / \mathrm{F}_{\mathrm{m}}$ in the second experiment under the higher PPFD. The plants with negative values for night $\Delta \mathrm{F}_{\mathrm{v}} / \mathrm{F}_{\mathrm{m}}$ were no longer able to recover from photoinhibition associated with drought even after full night recovery and thus required rehydration. This behavior was confirmed by $\Psi_{\mathrm{w}}$ of around $-1.5 \mathrm{MPa}$ for 'Ouro Negro' in the first experiment, and for 'A 285' and 'A 222' in the second experiment on the eighth day of stress (Fig. 1). Thus, $\Psi_{\mathrm{w}}$ and night $\Delta \mathrm{F}_{\mathrm{v}} / \mathrm{F}_{\mathrm{m}}$ can both be used for indication of the need of rehydration. In both the experiments, the plants of all the genotypes showed night $\Delta \mathrm{F}_{\mathrm{v}} / \mathrm{F}_{\mathrm{m}}$ values close to non-stressed plants after three days of rehydration indicating no irreversible effect on PS II. However, as clarified for day $\Delta \mathrm{F}_{\mathrm{v}} / \mathrm{F}_{\mathrm{m}}$ (Fig. $4 A, C$ ), the values of $F_{\mathrm{v}} / \mathrm{F}_{\mathrm{m}}$ before dawn or after sundown (Fig. 2) discriminated between different genotype responses better; however, the night $\Delta \mathrm{F}_{\mathrm{v}} / \mathrm{F}_{\mathrm{m}}$ analysis (Fig. $4 B, D$ ) and $\Psi_{\mathrm{w}}$ (Fig. 1) were useful for indicating drought intensity and a threshold value for recovery by rehydration.

The LSPC, which is formed from more than $50 \%$ by ribulose-1,5-bisphosphate carboxylase/oxygenase in $\mathrm{C}_{3}$ plants and is responsible for $\mathrm{CO}_{2}$ assimilation (Long et al. 2006) is an important trait with a high heritability and correlation to yield (Barros et al. 2016). In this study, 'Diplomata' in the first experiment and 'A 285' in the second, showed a higher LSPC in the well hydrated plants (Table 1), but 'Diplomata' also showed higher $F_{\mathrm{v}} / \mathrm{F}_{\mathrm{m}}$ (Fig. 2) and $\Phi_{\text {PSII }}$ values (Fig. $3 A, B$ ) than the others during drought in both experiments indicating a relationship between LSPC, related to Rubisco activity, and $\Phi_{\text {PSII }}$ under stress for this genotype. Protein synthesis and cell growth are the most drought sensitive processes (Kramer and Boyer 1995), but in this study, in both the experiments, LSPC in the plants R was very similar to or even higher than in the plants BS for all the genotypes (Table 1) showing a rapid recovery of photosynthesis as shown by Santos et al. (2006) probably due to an increased protein synthesis and cell growth with rehydration.

In the first experiment even under the severe water deficit $\left(\Psi_{\mathrm{w}}=-1.5 \mathrm{MPa}\right)$, there was no reduction in the number of pods per plant and grain weight per plant for 'Ouro Negro', only in the number of grains per plant, whereas for 'Diplomata', drought significantly reduced all yield components compared with control plants (Table 2). However, in the second experiment with the higher PPFD, which showed an early reduction in $\mathrm{F}_{\mathrm{v}} / \mathrm{F}_{\mathrm{m}}$ (Fig. 2) and $\Phi_{\text {PSII }}$ (Fig. 3A,B), all the yield components of the three genotypes were reduced (Table 2). Comparison of the yield components among the water-stressed genotypes in the first experiment showed a higher grain weight per plant for 'Diplomata' than for 'Ouro Negro' (Table 2), whereas among the genotypes in the second experiment, a higher 
number of pods per plant was observed for 'Diplomata' compared with 'A 285' and 'A 222', and a significantly higher number of grains per plant and grain weight per plant were verified for 'Diplomata' and 'A 285' than for 'A 222' (Table 2). 'A 285' and 'A 222' were considered drought tolerant genotypes in a previous study (Santos et al. 2009). In this study, 'Diplomata' and 'A 285' showed a higher LSPC (Table 1) and yield than 'A 222' under drought (Table 2), but 'Diplomata' maintained a higher $\Psi_{\mathrm{w}}$ (Fig. 1), $\mathrm{F}_{\mathrm{v}} / \mathrm{F}_{\mathrm{m}}$ (Fig. 2), and $\Phi_{\mathrm{PSII}}$ (Fig. $3 A, B$ ) with a high LSPC (Table 1), which ensured its high yield in both the experiments (Table 2).

In conclusion, the thermotolerant genotype 'Diplomata' (Pimentel et al. 2013) can also be considered more drought tolerant than the other genotypes studied as suggested by Foyer (2019). The values of $F_{v} / F_{m}$ evaluated on naturally dark-adapted leaves after sundown and before dawn when $\Psi_{\mathrm{w}}$ was also measured showed more significant differences under drought than the parameters measured in light-adapted leaves. Furthermore, analysis of day $\Delta \mathrm{F}_{\mathrm{v}} / \mathrm{F}_{\mathrm{m}}$ and night $\Delta \mathrm{F}_{\mathrm{v}} / \mathrm{F}_{\mathrm{m}}$ was indicative of differences in the intensity of and recovery from photoinhibition in the genotypes. Similar to the threshold values for $\Psi_{\mathrm{w}}$, a negative value for night $\Delta \mathrm{F}_{\mathrm{v}} / \mathrm{F}_{\mathrm{m}}$ could be used to indicate the need for rehydration in order to promote plant recovery. Additionally, more studies are needed to confirm the early $\mathrm{F}_{\mathrm{v}} / \mathrm{F}_{\mathrm{m}}$ decay under drought and PPFD above $800 \mu \mathrm{mol} \mathrm{m} \mathrm{m}^{-2} \mathrm{~s}^{-1}$, as seen in the field.

\section{References}

Baker, N.R.: Chlorophyll fluorescence: A probe of photosynthesis in vivo. - Annu. Rev. Plant Biol. 59: 89-113, 2008.

Barros, R.L.N., Oliveira, L.B., Magalhães, W.B., Pimentel, C.: Growth and yield of common bean as affected by seed inoculation with Rhizobium and nitrogen fertilization. - Exp. Agr. 54: 16-30, 2016.

Blum, A.: Plant breeding for water-limited environments, Springer, New York 2011.

Bradford, M.M.: A rapid and sensitive method for the quantitation of microgram quantities of protein utilizing the principle of protein-dye binding. - Anal. Biochem. 72: 248-254, 1976.

Ferreira, D.F.: Sisvar: a computer statistical analysis system. Ciên. Agrotecnol. 35: 1039-1042, 2011.

Foyer, C.H.: Legumes - The art and science of environmentally sustainable agriculture. Plant, Cell Environ. 42: 1-5, 2019.

Głowacka, K., Kromdijk, J., Kucera, K., Xie, J., Cavanagh, A.P., Leonelli, L., Leakey, A.D.B., Ort, D.O., Niyogi, K.K., Long, S.P.: Photosystem II Subunit S overexpression increases the efficiency of water use in a field-grown crop. - Natur. Commun. 9: 868, 2018.

Hungria, M., Campo, R.J., Mendes, I.C.: Benefits of inoculation of the common bean (Phaseolus vulgaris) crop with efficient and competitive Rhizobium tropici strains. - Biol. Fertil. Soils 39: 88-93, 2003.

Kramer, P., Boyer, J.: Water Relations of Plants and Soils. Academic Press, San Diego, 1995.

Levitt, J., Wibe, H.H., Boyer, J.S., McWilliam, J.R., Richie, J.T., Blum, A., Bidinger, J.: Adaptation of Plants to Water and High Temperature Stress: Summary and Synthesis. - In: Kramer, P.J. (ed.): Adaptation of Plants to Water and High Temperature Stress. Pp. 437-456. Wiley Interscience, New York 1980.

Long, S.P., Zhu, X.G., Naidu, S.L., Ort, D.R.: Can improvement in photosynthesis increase crop yields? - Plant Cell Environ. 29: 315-330, 2006.

Maxwell, K., Johnson, G.N.: Chlorophyll fluorescence - a practical guide. - J. exp. Bot. 51: 659-668, 2000.

Mishra, K.B., Iannacone, R., Petrozza, A., Mishra, A., Armentano, N., La Vecchia, G., Trtílek, M., Cellini, F., Nedbal, L.: Engineered drought tolerance in tomato plants is reflected in chlorophyll fluorescence emission. - Plant Sci. 182: 79-86, 2012.

Murchie, E.H., Lawson, T.: Chlorophyll fluorescence analysis: a guide to good practice and understanding some new applications. - J. Exp. Bot. 13: 3983-3998, 2013.

Neil, S., Barros, R.; Bright J., Desikan, R., Hancock, J., Harrison, J., Morris, P., Ribeiro, D., Wilson I.: Nitric oxide, stomatal closure, and abiotic stress. J. exp Bot. 59: 165-176, 2008.

Pimentel, C., Davey, P.A., Juvik, J.A., Long, S.P.: Gene loci in maize influencing susceptibility to chilling dependent photoinhibition of photosynthesis. - Photosynth. Res. 85: 319 326, 2005.

Pimentel, C., Laffray, D., Louguet, P.: Intrinsic water use efficiency at the pollination stage as a parameter for drought tolerance selection in Phaseolus vulgaris L. - Physiol. Plant. 106: 184-198, 1999.

Pimentel, C., Ribeiro, R.V., Machado, E.C., Dos Santos, M.G., De Oliveira, R.F.: In vivo temperature limitations of photosynthesis in Phaseolus vulgaris L. - Environ. exp. Bot. 91: 84-89, 2013.

Santos, M.G., Ribeiro, R.V., Machado, E.C., Pimentel, C.: Photosynthetic parameters and leaf water potential of five common bean genotypes under mild water deficit. - Biol. Plant. 53: 229-236, 2009.

Santos, M.G., Ribeiro, R.V., Oliveira, R.F., Machado, E.C., Pimentel, C.: The role of inorganic phosphate on photosynthesis recovery of common bean after a mild water deficit. - Plant Sci. 170: 659-664, 2006.

Schreiber, U., Bilger, W., Neubauer, C.: Chlorophyll fluorescence as a nonintrusive indicator for rapid assessment of in vivo photosynthesis. - In: Schulze, E.D., Caldwell, M.M. (ed.): Ecophysiology of Photosynthesis. Pp. 49-70. Springer, Berlin 1994.

Takahashi, S., Badger, M.R.: Photoprotection in plants: a new light on photosystem II damage. - Trends Plant Sci. 16: 5360, 2011.

Vieira, C., Júnior, T.J.P., Borém, A. (ed.): Common bean. $2^{\text {nd }}$ Ed., UFV - Universidade Federal de Viçosa, Viçosa 2006. [In Port.] 